развитие осложнений со стороны миокарда, сосудов и почечной ткани на самых первых этапах.

$* * *$

1. Мухин Н.А. Нефрология. Национальное руководство. Краткое издание /Н.А. Мухин - М.: ГЭОТАР - Медиа, 2014. - 608 с.

2. Серов, В. А. Кардиоренальные взаимоотношения у больных с хронической сердечной недостаточностью: автореф. дис. ... канд. мед. наук / В. А. Серов ; М-во здравоохранения РФ, Ульяновский гос. ун-т.- Ульяновск, 2011. - 41 с.

3. Шилов Е.М. Национальные клинические рекомендации по лечению отдельных нефропатий /Е.М. Шилов - М.: «Белый Ветер», 2015. - 312 с.

4. Шилов Е.М. Хроническая болезнь почек и нефропротективная терапия. Методическое руководство для врачей /Е.М. Шилов - Москва, 2012. - 76 с.

5. Боровкова Н.Ю., Ильина А.С., Спасский А.А. Острое почечное повреждение у больных инфарктом миокарда в клинической практике /Фарматека. - 2016. - №10. - С. 8-11.

\title{
Moskalets O.V. \\ Prognostic value of cell adhesion molecules in children with atypical hemolytic uremic syndrome
}

Moscow Regional Research Clinical Institute named after M.F.Vladimirskij

(Russia, Moscow)

doi 10.18411/gq-30-11-2018-08

idsp sciencerussia-30-11-2018-08

Introduction. Hemolytic uremic syndrome (HUS) is a rare, but severe condition characterized by simultaneous development of acute renal injury, non-immune hemolytic anemia and thrombocytopenia. There are 2 main forms of this disorder: typical HUS (tHUS), caused by Shiga-toxin producing Escherichia coli and atypical HUS (aHUS), associated with mutations of genes encoding complement factors or autoantibodies.[3,4]. Eculizumab has proved to be a most efficient therapy for patients with aHUS, bloking C5 and thus the formation of terminal complement cascade [2]. However, optimal duration of eculizumab therapy and whether it can be dicontinuated in remission still remains unclear [1,5]. Endothelial activaton followed by disfunction might indicate subclinical complement activation in remission of aHUS. The purpose of this study was to assess the levels of cell adhesion molecules as markers of endothelial activaton in these patients.

Patients and methods. 58 children with aHUS remission were examined. 22 children were treated with eculizumab (group1), 16 children did not receive this drug (group 2 ). The duration of remission was $22 \pm 20$ months and $22 \pm 21$ months respectively.

Serum concentrations of C3 complement component, soluble intracellular adhesion molecule-1 (sICAM-1) and vascular cell adhesion molecule (sVCAM-1) were determined by enzyme-linked immunosorbent assay. Leucocyte and thrombocyte counts, hemoglobin, creatinine, urea, LDG levels were determined as well.

Results. Serum levels of C3, sICAM-1 and sVCAM-1 were within normal age ranges in both groups. Children from group 1 showed increased sICAM-1 levels $(478 \pm 102$ $\mathrm{pg} / \mathrm{ml}$ vs $343 \pm 50 \mathrm{pg} / \mathrm{ml})$ compared to group $2(\mathrm{p}<0,05)$. There was a tendency to higher sVCAM-1 levels in group 1 (statistically unreliable). No differences in thrombocyte counts, hemoglobin, creatinin, creatinine, urea, LDG and C3 levels were revealed. Leucocyte counts in group 1 were higher $(7,5 \pm 2,3$ vs $5,8 \pm 1,3, \mathrm{p}<0,05)$.

Conclusion. In children free of eculizumab therapy no signs of subclinical complement activation or endothelial disfunction were found. Normal serum levels of C3, sICAM-1 and sVCAM-1 prove that normal endothelial state could be restored in aHUS and this condition is maintained after discontinuation of the targeted therapy. These results 
suggest that C3, sICAM-1 and sVCAM-1 monitoring may be useful for further management of these patients and for prediction of relapses.

\section{$* * *$}

1. Carter S., Hewitt I., Kausman J. Long-term remission with eculizumab in atypical haemolytic uraemic syndrome. //Nephrology(Cariton). - 2017. - V22, Suppl.1. - P.7-10.

2. Ito N., Hataya H., Saida K. et al. Efficacy and safety of eculisumab in childhood atypical haemolytic uremic syndrome in Japan. // Clin.Exp.Nephrol. - 2016. - V.20(2). - P.265-272.

3. Kavanagh D., Richards, A. Atkinson J. Complement regulatory genes and haemolytic uremic syndromes. //Annu. Rev. Med. - 2008. - V.59. - P.293-309.

4. Karpman D., LooseL., Tati R., Arvidsson I. Haemolitic uraemic syndrome // J. of Int. Medicine. - 2017. V.281(2). - P.123-148.

5. Rodrigues E., Barrios C., Soller G. Should eculizumab be continued in patients with atypical hemolytic uremic syndrome? //Clin. Kydney J. - 2017. - №3.- P.3230-322. 